\title{
Current status and perspectives of rare earth catalytic materials and catalysis
}

\author{
Wangcheng Zhan, Yun Guo, Xueqing Gong, Yanglong Guo, Yanqing Wang, Guanzhong Lu* \\ Key Lab for Advanced Materials and Research Institute of Industrial Catalysis, East China University of Science and Technology, Shanghai 200237, \\ China
}

\section{A R T I C L E I N F O}

Article history:

Received 13 June 2014

Accepted 1 July 2014

Published 20 August 2014

\section{Keywords:}

Rare earth catalytic material

Environment protection

Clear energy

Density functional theory calculation

Ceria catalysis

\begin{abstract}
A B S T R A C T
Rare earth elements possess $4 f$ orbitals without full electron occupancy and lanthanide contraction. This characteristic results in their unique catalytic performance when they are used as active components or as catalyst supports. Research into and the development of rare earth catalytic materials will significantly promote the high-efficiency utilization of abundant rare earth elements, such as lanthanum and cerium. Currently, rare earth catalytic materials play an important role in such areas as the petroleum chemical industry, the catalytic combustion of fossil fuels, automotive emissions control, the purification of industrial waste air, and solid solution fuel cells. In this paper, we review the application of and recent research progress that has been made on rare earth catalytic materials, including relative theoretical research. The effects of rare earth elements on the structure, activity, and stability of the catalysts of interest are described.
\end{abstract}

(C) 2014, Dalian Institute of Chemical Physics, Chinese Academy of Sciences. Published by Elsevier B.V. All rights reserved.

\section{Introduction}

Rare earth (RE) elements contain the lanthanide elements with atomic number from 57 to 71 , and scandium and yttrium, which have similar electronic structures and chemical properties to lanthanide elements. Rare earth elements possess $4 f$ orbitals without full electron occupancy and lanthanide contraction. This characteristic results in their unique chemical properties when they are used as catalysts or catalytic components. This is especially evident for cerium (Ce) and lanthanum (La). Since the middle of the 1960s, the catalytic performance of RE catalytic materials has been studied widely in the world. Their applications in the chemical processing field include the petroleum chemical industry, the catalytic combustion of fossil fuels, automotive emissions control, the purification of indus- trial waste air, olefin polymerization, and fuel cells (solid oxide fuel cells). Based on their material composition, RE catalytic materials can be divided into the RE composite oxides, RE-noble metal catalysts, RE-zeolite catalysts, and so on. The presence of RE materials in catalysts can improve their ability to store oxygen, the lattice oxygen reactivity of the materials, and the dispersion of active metals on the supports; reduce the noble metal dosage; and enhance their thermal stability. This leads to a significant improvement in catalyst performance.

The applications and recent progress made with RE catalytic materials or in RE catalysis in several important processes related to energy production and utilization, and in environmental protection have been reviewed in this paper. Relative theoretical research and challenges in the development of novel RE catalytic materials have also been discussed.

\footnotetext{
* Corresponding author. Tel/Fax: +86-21-64252923; E-mail: gzhlu@ecust.edu.cn This work was supported by the National Basic Research Program of China (973 Program, 2010CB732300), the National High Technology Research and Development Program of China (863 Program, 2012AA111717), the Fundamental Research Funds for the Central Universities (WK1214007), and the National Natural Science Foundation of China (21273150, 21103048).

DOI: 10.1016/S1872-2067(14)60189-3 | http://www.sciencedirect.com/science/journal/18722067 | Chin. J. Catal., Vol. 35, No. 8, August 2014
} 


\section{Catalysts for the petroleum chemical industries}

Fluid catalytic cracking (FCC) is an important procedure in petroleum refining, in which zeolite catalysts have been used widely because of their high surface area, highly ordered pore structure, high acid density, shape selectivity, and so on. As early as the 1960s, RE-exchanged Y zeolites were used as cracking catalysts instead of amorphous silica-alumina catalyst, thereby increasing the gasoline yield by more than $10 \%$. This has been termed the revolution of the oil refining industry.

The introduction of RE materials into zeolites can be used to adjust the amount and intensity distribution of the acid sites. The amount and method of $\mathrm{RE}^{3+}$ introduction influences the zeolite acid properties significantly and results in different zeolite-based FCC catalyst activities [1,2]. The high Brönsted acidity of RE-Y is related to its high RE content owing to the hydrolysis reaction, $\mathrm{RE}^{3+}+\mathrm{H}_{2} \mathrm{O} \leftrightarrow[\mathrm{REOH}]^{2+}+\mathrm{H}^{+}$, that occurs in the zeolitic cavities. For example, there is $\sim 17 \% \mathrm{RE}_{2} \mathrm{O}_{3}$ in $\mathrm{RE}-\mathrm{Y}$ vs. $6 \%-7 \% \mathrm{RE}_{2} \mathrm{O}_{3}$ in RE-ultrastable Y (RE-USY) and none in USY $(\mathrm{RE}=\mathrm{Ce}$ or La), and the RE-Y catalyst exhibits a higher FCC activity [3,4].

FCC catalysts are generally used at high temperatures and in hydrothermal environments in the petroleum industry. These conditions usually induce a decline in the crystal degree, a deterioration of the aluminum leaching framework and even a collapse in the zeolite structure, which results in a deactivation of zeolite-based FCC catalysts. The introduction of RE materials into the zeolite results in a retention of the aluminum framework and an improved zeolite structure stability [5-8]. As shown in Fig. 1, $\mathrm{La}^{3+}$ has replaced $\mathrm{Na}^{+}$or $\mathrm{H}^{+}$in the $\mathrm{Y}$ zeolite and is situated inside the $\beta$ cage [8]. As a result, it stabilizes the $Y$ zeolite framework and improves the hydrothermal stability.

To produce lead-free gasoline, RE-Y cracking catalysts with high RE content have transited to RE-exchanged ultrastable $Y$ with low RE content. As a result, the olefin content in the FCC gasoline is high $(\sim 40 \%-45 \%$, and up to $65 \%)$, which does not conform to current global requirements for the development of clean fuel. In contrast, compared with Y zeolite, ZSM-5 zeolite has a small pore size and can cause the olefin in the gasoline to crack selectively to $\mathrm{C} 3$ and $\mathrm{C} 4$ olefins. This increases the propylene content in FCC gasoline, and is accompanied by a decrease in olefin content [9]. For the RE-exchanged Y zeolite, the

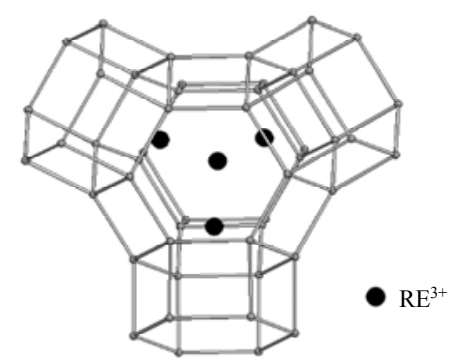

Fig. 1. Distribution of $\mathrm{RE}^{3+}$ inside $\beta$ cage of RE-Y zeolite [8].

introduction of RE material into ZSM- 5 zeolites can also effectively adjust the amount and intensity distribution of acid sites to reduce the olefin content in FCC gasoline [10-12]. For example, the ZSM-5 zeolite modified with La possessed more strong acid sites compared with ZSM-5 zeolite. Olefin conversion and propylene selectivity increased in the cracking reaction of FCC gasoline for the La-modified ZSM-5 zeolite, and resulted in an olefin conversion of $74.3 \%$, an olefin mass fraction of $18.2 \%$ in cracking gasoline, and a propylene selectivity of $45.9 \%$ at 550 ${ }^{\circ} \mathrm{C}$, at atmospheric pressure and with steam [13]. Similarly, in the post-treatment of naphtha using monolithic catalysts with zeolite washcoat, the introduction of RE material into ZSM-5 zeolite by ion-exchange or precipitation could promote the conversion of olefin in naphtha and also increase propylene selectivity. The gaseous products consisted mainly of up to $60 \%$ propylene and C4 olefin and the propylene yield was $\sim 31 \%$, while the olefin content in naphtha could be reduced to $15 \%$ [14].

In addition to their irreplaceable role in zeolite-based FCC catalysts, RE elements are also important co-catalysts, and play an important role in ethanol catalytic dehydration to ethylene [15], lactic acid dehydration to acrylic acid [16], the direct transformation of $n$-butane to iso-butene [17], double bond position isomerization [18] and the acylation of toluene [19]. $\mathrm{RE}$ materials can also be used as the main active component in many catalysts. For example, Ce/AlPO-5 showed high catalytic performance in the oxidation of cyclohexane without solvent. As shown in Table 1 , at $0.5 \mathrm{MPa} \mathrm{O}_{2}$ and $140{ }^{\circ} \mathrm{C}$ for $4 \mathrm{~h}$, the conversion of cyclohexane was $13.5 \%$, and the total selectivity of cyclohexanol and cyclohexanone was above 92\%. However, trace amount of oxidative products were detected over the

Table 1

Catalytic performance of Ce/AlPO-5 for cyclohexane oxidation [20].

\begin{tabular}{|c|c|c|c|c|c|}
\hline \multirow{2}{*}{ Catalyst } & \multirow{2}{*}{ Time $(\mathrm{h})$} & \multirow{2}{*}{ Atmosphere (MPa) } & \multirow{2}{*}{ Conversion (\%) } & \multicolumn{2}{|c|}{ Selectivity (\%) } \\
\hline & & & & Cyclohexanol & Cyclohexanone \\
\hline AlPO-5 & 4 & $\mathrm{~N}_{2} / 0.5$ & - & - & - \\
\hline $\mathrm{Ca}(\mathrm{A}) / \mathrm{AlPO}-5$ & 4 & $\mathrm{~N}_{2} / 0.5$ & - & - & - \\
\hline $\mathrm{Ca}(\mathrm{A}) / \mathrm{AlPO}-5$ & 4 & $\mathrm{O}_{2} / 0.5$ & 13.5 & 42 & 50 \\
\hline $\mathrm{Ca}(\mathrm{A}) / \mathrm{AlPO}-5^{\mathrm{a}}$ & 4 & $\mathrm{O}_{2} / 0.5$ & 13.0 & 40 & 51 \\
\hline $\mathrm{Ca}(\mathrm{B}) / \mathrm{AlPO}-5$ & 4 & $\mathrm{O}_{2} / 0.5$ & 12.0 & 35 & 58 \\
\hline $\mathrm{Ca}(\mathrm{C}) / \mathrm{AlPO}-5$ & 4 & $\mathrm{O}_{2} / 0.5$ & 11.5 & 30 & 60 \\
\hline $\mathrm{Mn} / \mathrm{AlPO}-5^{42}$ & 24 & Air/1.0 & 6.0 & 19 & 43 \\
\hline $\mathrm{Mn} / \mathrm{AlPO}-5^{42 \mathrm{~b}}$ & 24 & Air/1.0 & 16.5 & 20 & 43 \\
\hline $\mathrm{CeO}_{2}$ & 4 & $\mathrm{O}_{2} / 0.5$ & 7.0 & 30 & 52 \\
\hline
\end{tabular}

Reaction conditions: $18.5 \mathrm{mmol}$ cyclohexane, $10 \mathrm{mg}$ catalyst, at $140{ }^{\circ} \mathrm{C}$.

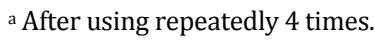

${ }^{\mathrm{b}}$ Small amounts (3 wt\% cyclohexane) of hydroquinone (free-radical scavenger) added. 
pure AlPO-5 catalyst [20]. Similarly, almost $13 \%$ cyclohexane conversion can be achieved over the Gd-AlPO- 5 catalyst at 0.5 $\mathrm{MPa} \mathrm{O}_{2}, 140{ }^{\circ} \mathrm{C}$ and $4 \mathrm{~h}$ reaction. The total selectivity to cyclohexanol and cyclohexanone was up to $92 \%$ [21].

\section{Catalytic combustion of natural gas and other fossil fuels}

Catalytic combustion is a heterogeneous complete oxidation reaction between fuel and air on the catalyst surface. It has recently received attention as an environmentally friendly process. Compared with conventional flame combustion, catalytic combustion has the followed merits: (1) low light-off temperature, (2) stable combustion in a large oil/gas ratio range, (3) high combustion efficiency, (4) lower exhaust emissions, and (5) low noise. The high activity and high temperature resistant oxidation catalyst is key for the catalytic combustion technique [22-24].

The catalytic combustion of natural gas has been attracting the most attention among natural gas, liquefied petroleum gas, and coal gas. Catalysts for the combustion of natural gas can be classified as follows: (1) supported noble metal (Pt, Pd) catalysts, (2) supported non-noble metal ( $\mathrm{Ni}, \mathrm{Co}, \mathrm{Mn}, \mathrm{Cu}$, and $\mathrm{Fe}$ ) oxide catalysts, and (3) composite oxide catalysts (perovskite, spinel, and hexaaluminate containing the RE elements). Among these catalysts, supported noble metal catalysts, especially Pd, are recognized as the best catalysts for the catalytic combustion of natural gas [24,25]. Recently, Cargnello et al. [26] exploited modular Pd@CeO ${ }_{2}$ core-shell subunits on functionalized $\mathrm{Al}_{2} \mathrm{O}_{3}$ (Fig. 2). The special configuration of the hierarchical catalyst led to exceptionally high performance for the catalytic combustion of methane with reduced amounts of Pd and ceria $\left(\mathrm{CeO}_{2}\right)$. The complete conversion of $\mathrm{CH}_{4}$ was observed for a gas stream of $0.5 \mathrm{vol} \% \mathrm{CH}_{4}$ and $2.0 \mathrm{vol} \% \mathrm{O}_{2}$ in $\mathrm{Ar}$ at a space velocity of $200000 \mathrm{ml} \mathrm{g}^{-1} \mathrm{~h}^{-1}$ at $\sim 400{ }^{\circ} \mathrm{C}$. However, the nature and character of the support affects the interaction between Pd and the support significantly, and results in different catalyst activities for methane combustion [27-30]. Although PdO particles dis-

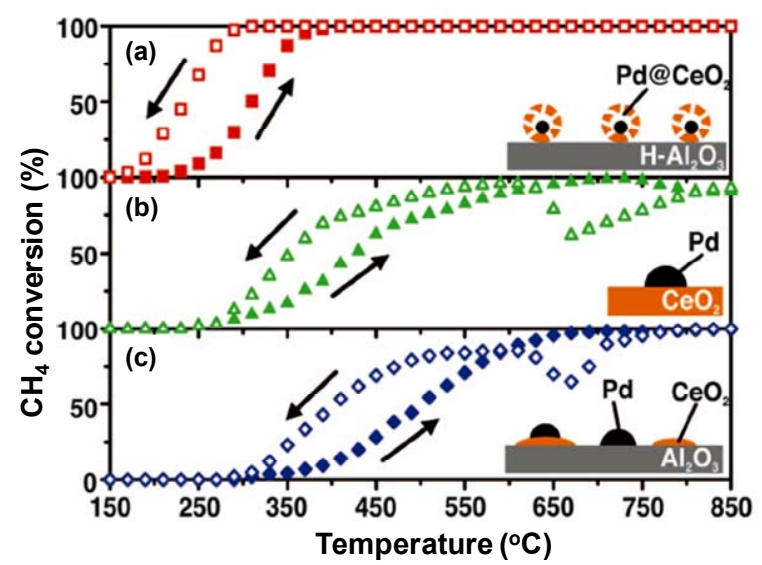

Fig. 2. Heating and cooling $\left(10^{\circ} \mathrm{C} / \mathrm{min}\right)$ light-off curves of $\mathrm{CH}_{4}$ conversion against temperature for the three catalyst formulations used [26]. (a) $\mathrm{Pd} @ \mathrm{CeO}_{2} / \mathrm{Al}_{2} \mathrm{O}_{3}$ core-shell catalyst; (b) $\mathrm{Pd} / \mathrm{CeO}_{2}$ prepared by incipient wetness impregnation; (c) $\mathrm{Pd} / \mathrm{CeO}_{2} / \mathrm{Al}_{2} \mathrm{O}_{3}$ prepared by impregnation. persed on the oxide support exhibit the highest activity for methane combustion, they still suffer from deactivation at high temperature (above $700{ }^{\circ} \mathrm{C}$ ) because of the formation of metallic Pd from PdO particles [31]. One possible approach for avoiding the formation of metallic $\mathrm{Pd}$ is to disperse $\mathrm{Pd}$ on reducible supports, such as $\mathrm{CeO}_{2}[32,33]$. Hoflund et al. [34] tested the effect of semiconductor properties of $\mathrm{CeO}_{2}$ on the reactivity of $\mathrm{Pd} / \mathrm{CeO}_{2}$ for methane oxidation, and the reactivity order was obtained as follows, $\mathrm{Pd} /$ nanocrystalline $\mathrm{CeO}_{2}>$ nanocrystalline $\mathrm{CeO}_{2}>\mathrm{Pd} /$ polycrystalline $\mathrm{CeO}_{2}$. Furthermore, the incorporation of metal ions with low valency into $\mathrm{CeO}_{2}$ can increase the oxygen vacancy concentration and mobility, and enhance its catalytic activity for methane combustion $[35,36]$. The non-steady activity behavior of supported noble-metal catalysts used in methane combustion has received little attention, even though methane combustion over the supported noble-metal catalysts has been the subject of a considerable number of recent publications. The introduction of $\mathrm{CeO}_{2}$ into $\mathrm{Pd} / \mathrm{Al}_{2} \mathrm{O}_{3}$ catalysts can restrain oscillatory behavior from the reciprocal transformation between $\mathrm{PdO}$ and $\mathrm{Pd}$ in methane combustion, because of the oxygen storage/release capacity of $\mathrm{CeO}_{2}$ [37].

Although supported noble metal catalysts show a high activity for the catalytic combustion of methane, they deactivate gradually at high temperature owing to the sintering or evaporation of noble metals. In contrast, oxide catalysts exhibit excellent thermal stability and have attracted increasing attention.

Hexaaluminate has an excellent structural stability and its activity for catalytic oxidation can be improved when transition metal ions with two or more different charges displace those ions in $\mathrm{A}$ and $\mathrm{B}$ sites to form $\mathrm{A}_{1-x} \mathrm{~A}^{*} \mathrm{~B}_{x} \mathrm{Al}_{12-x} \mathrm{O}_{19}$ [38-43]. Zarur and Ying [44] prepared discrete barium hexaaluminate (BHA) nanoparticles by the reverse microemulsion method, which displayed excellent methane combustion activity, owing to their high surface area and high thermal stability. Light-off of a stream of 1 vol\% $\mathrm{CH}_{4}$ in air at a high space velocity of $60000 \mathrm{~h}^{-1}$ was observed at a low temperature of $\sim 400{ }^{\circ} \mathrm{C}$ (Fig. 3) over the $\mathrm{CeO}_{2}$-BHA nanocomposite catalyst. Similarly, M-RE-Ba-Al-O

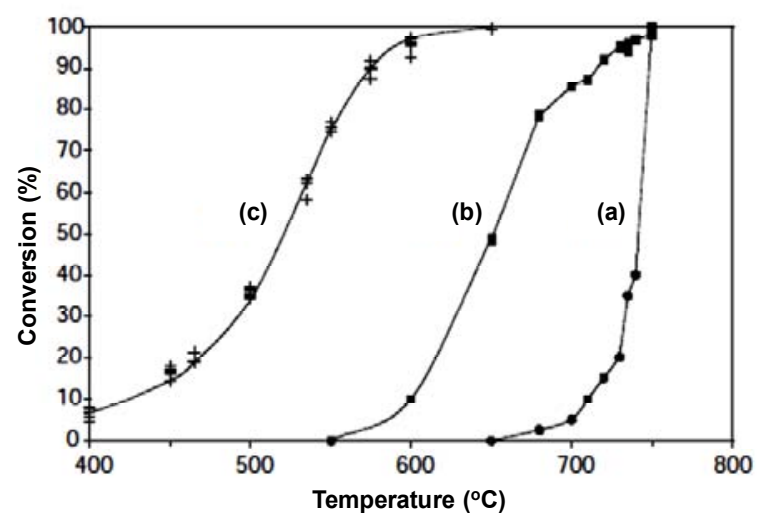

Fig. 3. Catalytic methane oxidation activities of sol-gel-derived conventional BHA (a), reverse-microemulsion-derived BHA nanoparticles (b), and reverse-microemulsion-derived $\mathrm{CeO}_{2}-\mathrm{BHA}$ nanocomposite (c). The reactant stream consisted of $1 \mathrm{vol} \% \mathrm{CH}_{4}$ in air (space velocity, 60000 $\mathrm{h}^{-1}$ ) [44]. 
hexaaluminate prepared by the fibrin template method also showed a high surface area and high thermal stability; after being calcined at $1050{ }^{\circ} \mathrm{C}$ for $15 \mathrm{~h}$ in a $10 \% \mathrm{H}_{2} \mathrm{O}$ atmosphere, its specific surface area exceeded $90 \mathrm{~m}^{2} / \mathrm{g}$ [45]. The urea combustion method can reduce the temperature and decrease the time needed to prepare the $\mathrm{Lax}_{x} \mathrm{Sr}_{1-x} \mathrm{MnAl}_{11} \mathrm{O}_{19}(x=0.2-0.8)$ hexaaluminates compared with conventional preparation methods, leading to its higher specific surface area and higher activity for methane combustion [46].

Perovskite-structured oxide $\left(\mathrm{ABO}_{3}\right)$ is another important oxide catalyst for methane combustion, because of its excellent thermal stability. Displacing some of the A or B ions with other metals can improve its catalytic activity, because different metal ion diameters can produce oxygen defects or vacancies. $\mathrm{LaMnO}_{3}$ and $\mathrm{LaCoO}_{3}$, as well as doped oxides, are the most representative among the perovskite-structured oxides. Because perovskite-structured oxides are usually prepared at high temperature, their specific surface area is low $\left(\leq 10 \mathrm{~m}^{2} / \mathrm{g}\right)$, which affects their activity and limits their application. It has been reported that the catalytic activity of perovskites for methane combustion is linearly dependent on its specific surface area in a certain range of specific surface area values $[47,48]$. Therefore, a technique to increase the specific surface area of perovskite-structured oxide has been of great research interest. One method is to design particular syntheses methods to increase the specific surface area and catalytic activity for methane combustion [49-51]. For example, ordered mesoporous $\mathrm{LaCoO}_{3}$ perovskite with a high BET surface area of $96.7 \mathrm{~m}^{2} / \mathrm{g}$ was synthesized by a nanocasting strategy using ordered mesoporous cubic (Ia3d) vinyl silica as the template [52]. This perovskite showed a much higher activity for methane combustion than the conventional bulk $\mathrm{LaCoO}_{3}$ perovskite. The light-off temperature $\left(T_{10}\right)$ and the half-conversion temperature ( $\left.T_{50}\right)$ were 335 and $470{ }^{\circ} \mathrm{C}$, respectively. Furthermore, $\mathrm{La}_{0.5} \mathrm{Ba}_{0.5} \mathrm{MnO}_{3}$ nanocubes prepared by the hydrothermal method also showed a much higher catalytic activity and thermal stability in methane combustion compared with nanoparticles prepared by the co-precipitation method [53]. After running at $560{ }^{\circ} \mathrm{C}$ for $50 \mathrm{~h}$ under the reaction conditions in methane combustion, the specific surface area of the nanoparticles decreased significantly, but the nanocubes maintained their specific surface area well.

Another route is to support perovskite oxide on supports (such as $\mathrm{Al}_{2} \mathrm{O}_{3}, \mathrm{SiO}_{2}, \mathrm{ZrO}_{2}$ ) with high surface area [54-56]. Cimino et al. [57] supported $\mathrm{LaMnO}_{3}$ on $\mathrm{La} / \gamma-\mathrm{Al}_{2} \mathrm{O}_{3}$ washcoated cordierite monoliths by using the deposition-precipitation method and investigated its catalytic activity for the autothermal combustion of lean methane mixtures. After $120 \mathrm{~h}$ of reaction at $800-1000{ }^{\circ} \mathrm{C}$, the fresh catalyst maintained its high stability and activity. Yi et al. [58] prepared crystalline $\mathrm{LaCoO}_{3}$ perovskite particles by a novel microwave-assisted process in the host pores of mesoporous SBA-15 silica. The resulting material exhibited considerably higher catalytic activity in methane combustion than the $\mathrm{LaCoO}_{3} / \mathrm{SBA}-15$ sample prepared by a conventional method, owing to a higher density of lattice defects achieved on the high surface area $\mathrm{LaCoO}_{3}$ nano-crystallites synthesized by the microwave-assisted process.

\section{Purification catalysts for automotive emission}

In recent years, the global automotive industry has developed rapidly and automotive emissions have increased the amount of atmospheric contaminants. Reducing single vehicle emissions and installing catalytic converters are the most efficient methods to control and purify automotive emissions, respectively. Therefore, the development of three-way catalysts with high performance to meet stricter emission standards would be of significant importance.

The composition of automotive emissions depends on used fuel (such as gasoline, diesel oil, liquefied petroleum gas, and compressed natural gas). In the case of diesel emission control, the treatment of particles and $\mathrm{NO}_{x}$ is more difficult than $\mathrm{CO}$ and unburned hydrocarbons (HC) [59-61]. When using compressed natural gas or liquefied petroleum gas as fuel, although the emission of $\mathrm{CO}$ and $\mathrm{HC}$ is much lower than that of ordinary automobile gasoline, $\mathrm{NO}_{\mathrm{x}}$ treatment is insufficient [62-64]. For the treatment of exhaust emission from lean-burn gasoline engines, the main difficulty is the selective reduction of $\mathrm{NO}_{x}$ under oxygen-rich conditions [65].

Based on developmental trends, challenges in the development of purification catalysts for automotive emissions are as follows: (1) to improve the selectivity of $\mathrm{NO}_{x}$ reduction for a wide range of air-fuel (A/F) ratios, especially under oxygen-rich conditions; (2) to lower the ignition temperature and reduce pollutant emissions during cold startup, and for this purpose, close-couple catalysts and catalysts for HC compound sorption have been developed [66,67]; and (3) to improve the endurance and high temperature stability of the catalysts. Nishihata et al. [68] prepared the Pd-perovskite catalyst $\mathrm{LaFe}_{0.57} \mathrm{Co}_{0.38} \mathrm{Pd}_{0.05} \mathrm{O}_{3}$ by the alkoxide method. Pd can move reversibly into and out of the perovskite lattice when the catalyst operates alternately between the oxidative and reductive atmospheres that are encountered typically in exhaust gas. This movement suppresses the growth of metallic Pd particles, and hence the catalyst retains its high activity during long-term use and ageing, as shown in Fig. 4.

Three-way catalysts for automotive emission control are made up of three constituents: the catalyst support (cordierite honeycomb support, metal support), washcoating (or active

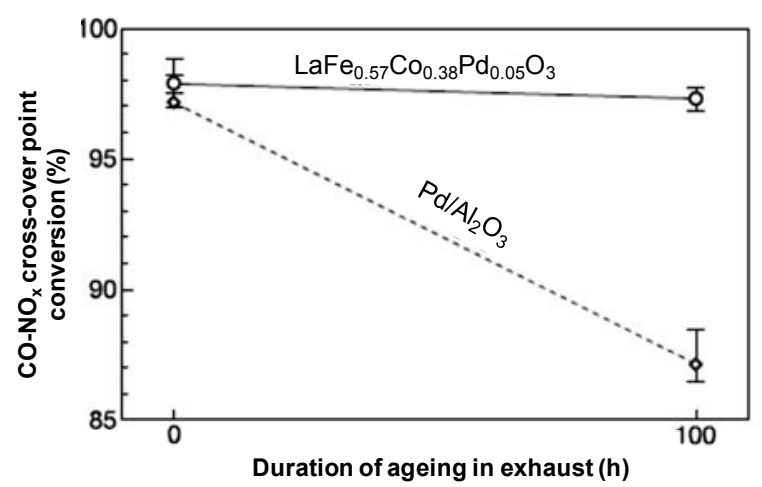

Fig. 4. Change in catalyst activity during ageing showing ageing dependence of the $\mathrm{CO}-\mathrm{NO}_{x}$ cross-over point conversion for $\mathrm{LaFe}_{0.57} \mathrm{Co}_{0.38} \mathrm{Pd}_{0.05} \mathrm{O}_{3} \quad$ (Pd-perovskite catalyst and impregnated $\mathrm{Pd} / \gamma-\mathrm{Al}_{2} \mathrm{O}_{3}$ catalyst) [68]. 
coating, the second support, which is composed mainly of $\mathrm{Al}_{2} \mathrm{O}_{3}, \mathrm{BaO}, \mathrm{CeO}_{2}$, and $\mathrm{ZrO}_{2}$ ), and active components (Pd, $\mathrm{Pt}, \mathrm{Rh}$ ). $\mathrm{RE}$ oxides have been used widely as catalysts for automotive emission control, since catalysts containing RE materials were developed to reduce automotive emissions by Libby in 1971 . $\mathrm{CeO}_{2}-\mathrm{ZrO}_{2}$ solid solution (CZO) is an important constituent in three-way catalysts, and it can enhance the oxygen storage ability; widen the operating window; improve the thermal stability of washcoating with large specific surface area; and improve the dispersion, anti-poisoning, and long-lasting properties of noble metals [69-71]. Therefore, $\mathrm{CeO}_{2}-\mathrm{ZrO}_{2}$ solid solutions are studied most intensively to improve their oxygen storage ability and thermal stability.

The oxygen storage capacity (OSC) of CZO comprises two parts: the total OSC and the dynamic OSC. To date, more attention has been given to studies of the total oxygen storage capacity of CZO and the influence of factors on its properties (Fig. 5) [72-74]. In general, it is believed that structural homogeneity and pretreatment conditions affect the total OSC of CZO significantly $[75,76]$. In contrast, factors that affect the dynamic OSC of CZO have rarely been studied. The ${ }^{180} 0 / 160$ isotopic exchange system combined with $\mathrm{CO}$ oxidation can be used to evaluate the dynamic oxygen release rate and the OSC [77].

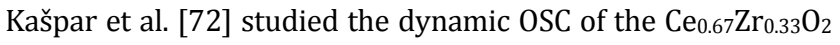
catalyst by $\mathrm{CO}-\mathrm{He}$ pulses and $\mathrm{CO}-\mathrm{O}_{2}$ dynamic pulses after redox and hydrothermal treatment, and reported that the dynamic OSC was related closely to the specific surface area of CZO with the same constituents [78].

Stability is another main factor in CZO performance. To improve the stability and OSC of CZO, CZO is often modified with other components to form three- or four-component $\mathrm{CeO}_{2}$ based oxygen storage materials, such as the CZO that contains $\mathrm{La} / \mathrm{Pr} / \mathrm{Nd} / \mathrm{Y} / \mathrm{Sm}$ and that was developed by Engelhard and Delphi companies [79] and the CZO that contains $\mathrm{Al}_{2} \mathrm{O}_{3}$ (ACZ) and that was developed by TOYOTA company $[75,80]$. $\mathrm{CeO}_{2}-\mathrm{ZrO}_{2}-\mathrm{La}_{2} \mathrm{O}_{3}(\mathrm{Ce} / \mathrm{Zr} / \mathrm{La}=1 / 1 / 0.06, \mathrm{~mol})$ was also prepared by inverse microemulsion in our laboratory. Its specific surface area can reach $126 \mathrm{~m}^{2} / \mathrm{g}$ after calcination at $1000{ }^{\circ} \mathrm{C}$, which shows excellent thermal stability [81].

$\mathrm{NO}_{x}$ abatement from diesel engine exhausts is a major challenge. The selective catalytic reduction (SCR) of $\mathrm{NO}_{x}$ with $\mathrm{NH}_{3}$

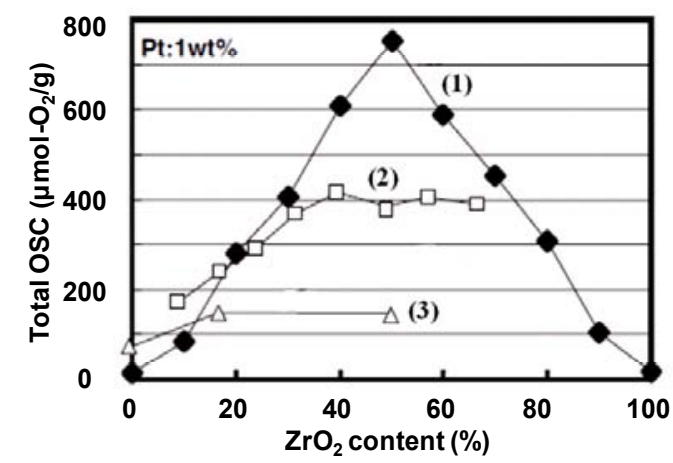

Fig. 5. Total OSC value of $\mathrm{CeO}_{2}$-zirconia mixed oxides as a function of zirconia content in the specimens: (1) R-CZ, reduced at $1200{ }^{\circ} \mathrm{C}$ by CO in the presence of graphite, followed by oxidation at $500{ }^{\circ} \mathrm{C}$ in air; (2) S-CZ, attrition-milled in ethanol; (3) $\mathrm{M}-\mathrm{CZ}$, heated at $700^{\circ} \mathrm{C}$ in air [75].
$\left(\mathrm{NH}_{3}-\mathrm{SCR}\right)$ is one of the most promising technologies for $\mathrm{NO}_{x}$ removal from diesel engines. $\mathrm{V}_{2} \mathrm{O}_{5}-\mathrm{WO}_{3}\left(\mathrm{MoO}_{3}\right) / \mathrm{TiO}_{2}$ has been used widely for $\mathrm{NO}_{x}$ removal from stationary sources and has been introduced into the market for diesel vehicles [82]. However, this SCR catalyst has at least two drawbacks: the toxicity of vanadium species and the rapid decrease of SCR activity at high temperature. Subsequently, metal-exchanged or loaded zeolites, such as Cu-ZSM-5 and Fe-ZSM-5, have also been studied extensively for $\mathrm{NH}_{3}-\mathrm{SCR}$ in recent years $[83,84]$. However, the low SCR activity at low temperature and the poor hydrothermal stability at high temperature limit their practical application. Therefore, significant efforts have been made to develop novel $\mathrm{NH}_{3}$-SCR catalysts with high SCR activity and $\mathrm{N}_{2}$ selectivity over a wide temperature range. Recently, Ce-W mixed oxide catalysts that were prepared by homogeneous precipitation exhibited nearly $100 \% \mathrm{NO}_{x}$ conversion from 250 to $425{ }^{\circ} \mathrm{C}$ for the selective catalytic reduction of $\mathrm{NO}_{x}$ with $\mathrm{NH}_{3}$ under an extremely high gas hourly space velocity (GHSV) of $500000 \mathrm{~h}^{-1}$ [85].

Besides the selective catalytic reduction of $\mathrm{NO}_{x}, \mathrm{NO}_{x}$ storage reduction (NSR) catalysts have also attracted much attention. Takahashi et al. $[86,87]$ studied NSR catalysts for the first time, i.e. $\mathrm{BaO} / \mathrm{Al}_{2} \mathrm{O}_{3}$, over which $\mathrm{NO}_{x}$ was adsorbed and oxidized to form nitrates under oxidizing conditions. Subsequently, the adsorbed $\mathrm{NO}_{x}$ was released and reduced to $\mathrm{N}_{2}$ under reducing atmosphere. $\mathrm{NO}_{x}$ storage and the reduction mechanism of NSR catalysts is shown in Fig. 6. Current research has shown that $\mathrm{CeO}_{2}$ has a good $\mathrm{NO}_{x}$ storage ability below $400{ }^{\circ} \mathrm{C}$, which broadens the temperature range of the NSR catalysts for $\mathrm{NO}_{x}$ purification of exhaust gas from lean-burn engines. Subsequently, much attention has been given to NSR catalysts using $\mathrm{CeO}_{2}$ or composite oxides containing Ce as a support. Piacentini et al. [88] studied Pt-Ba catalysts supported on $\mathrm{Al}_{2} \mathrm{O}_{3}, \mathrm{CeO}_{2}$, $\mathrm{SiO}_{2}$, and $\mathrm{ZrO}_{2}$. Pt-Ba catalysts supported on $\mathrm{CeO}_{2}$ and $\mathrm{ZrO}_{2}$ exhibit high catalytic performance because of their ability to stabilize carbonates. The Ce-Zr composite oxide was also usually used as an NSR catalyst support because of its high thermal stability $[89,90]$. On the other hand, $\mathrm{NO}$ oxidation to $\mathrm{NO}_{2}$ is an important step in NSR, because $\mathrm{NO}$ must be oxidized to $\mathrm{NO}_{2}$ before adsorption on the NSR catalyst storage components. Recently, Kim et al. [91] prepared a series of perovskite catalysts including $\mathrm{La}_{1-x} \mathrm{Sr}_{x} \mathrm{CoO}_{3}$ and $\mathrm{La}_{1-x} \mathrm{Sr}_{x} \mathrm{MnO}_{3}$ catalysts by the citrate method. $\mathrm{LaCoO}_{3}$ and $\mathrm{LaMnO}_{3}$ catalysts have a high catalytic activity for $\mathrm{NO}$ oxidation, and $\mathrm{LaCoO}_{3}$ is more active than $\mathrm{LaMnO}_{3}$, as shown in Fig. 7. However, the catalytic activity of $\mathrm{LaCoO}_{3}$ can be enhanced further by $10 \mathrm{~mol} \%$ substitution for

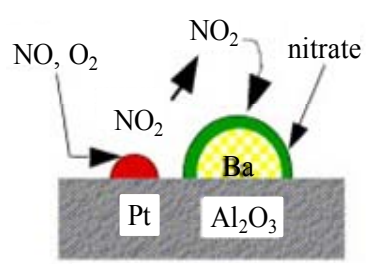

In Lean $\mathrm{A} / \mathrm{F}$

(Stored as nitrate)

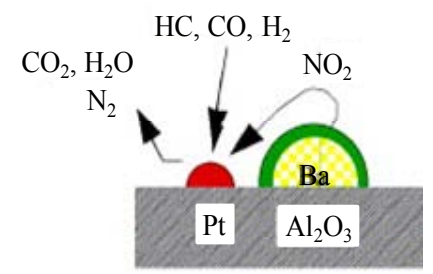

In Stoichiometric $\mathrm{A} / \mathrm{F}$ (Reduced to nitrogen)
Fig. 6. Possible mechanism of $\mathrm{NO}_{x}$ storage-reduction on NSR catalyst [87]. 


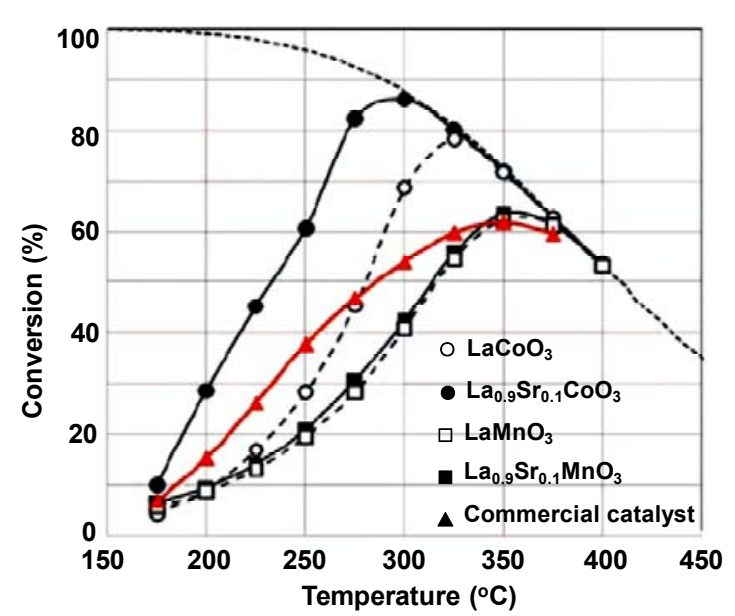

Fig. 7. NO oxidation activities for $\mathrm{LaCoO}_{3}, \mathrm{La}_{0.9} \mathrm{Sr}_{0.1} \mathrm{CoO}_{3}, \mathrm{LaMnO}_{3}$, $\mathrm{La} 0.9 \mathrm{Sr}_{0.1} \mathrm{MnO}_{3}$, and commercial diesel oxidation catalyst at a gas hourly space velocity of $30000 \mathrm{~h}^{-1} ; 400 \mathrm{ppm} \mathrm{NO}$ and $8 \% \mathrm{O}_{2}$ with the balance being $\mathrm{N}_{2}$ [91].

Sr, over which a NO conversion of $86 \%$ was obtained at $300{ }^{\circ} \mathrm{C}$, which represents a higher activity than that of the commercial Pt-based catalyst. The perovskite catalysts also show the potential to substitute Pt-based catalysts in lean $\mathrm{NO}_{x}$ trap catalysts.

\section{Catalytic purification of industrial waste air}

Besides automotive emissions, $\mathrm{SO}_{x}, \mathrm{NO}_{x}$, and volatile organic compounds (VOCs) from industrial processes are the main atmospheric pollutants. The key to solving the emission problem is to develop economic and highly efficient purification techniques, among which catalytic purification is the most effective method.

Flue gas desulfurization techniques can be classified into wet or dry methods on the basis of different desulfurizers. Owing to the limitations of wet desulfurization, dry desulfurization has been developed rapidly in recent years, and RE oxides have been used widely as absorbents or catalysts [92,93]. For example, $\mathrm{CeO}_{2} / \mathrm{Al}_{2} \mathrm{O}_{3}$ has been used as an absorbent to remove $\mathrm{SO}_{2}$ and $\mathrm{NO}_{x}$ in flue gas simultaneously, and the efficiency of desulfurization and denitrification were both higher than 90\% [94]. In catalytic oxidation desulfurization, $\mathrm{CeO}_{2}$ can oxidize $\mathrm{SO}_{2}$ to $\mathrm{SO}_{3}$ and adsorb $\mathrm{SO}_{x}$ to form sulfate, and then sulfate converts to elemental sulfur through reduction and the Claus reaction [95]. Therefore, $\mathrm{CeO}_{2}$ has been applied widely in the catalytic oxidation desulfurization of the fluid catalytic cracking unit [96]. Concurrently, La or Ce-based composite oxides with perovskite or fluorite-structure have also been studied widely in flue gas reduction desulfurization [97-99].

The catalytic oxidation of VOCs has been considered to be the most effective technique for the purification of organic exhaust gas with high concentration, because of its low operating temperature, high purification efficiency, and no secondary pollutants. In recent years, the catalytic purification of the following organic compounds has been studied: (1) benzene, toluene, and xylene; (2) chlorinated volatile organic compounds
(CVOCs); and (3) polycyclic aromatic hydrocarbons (PAHs), such as naphthalene and anthracene. In catalysts for VOC purification, the presence of rare earth elements can improve catalytic activity and thermal stability, and reduce the noble metal dosage. For example, catalysts containing rare earth oxide show higher activities for the purification of chlorinated organic compounds, including catalytic decomposition in the vapor (Fig. 8) [100,101] and catalytic combustion at low temperature $[102,103]$.

Recently, $\mathrm{CeO}_{2}$ has been found to exhibit a high catalytic activity for the catalytic combustion of chlorinated aliphatic hydrocarbons with low molecular weight and chlorinated aromatic hydrocarbons [103,104]. However, its activity diminishes rapidly because of the strong adsorption of $\mathrm{HCl}$ or $\mathrm{Cl}_{2}$ produced from the decomposition of CVOCs on the $\mathrm{CeO}_{2}$ surface, and a blocking of the active sites. Catalysts used in the catalytic combustion of CVOCs contain noble metals, transition metal oxides, and solid acid catalysts, and transition metal oxide catalysts can generally resist deactivation by chlorine poisoning. Therefore, $\mathrm{CeO}_{2}$-based composite oxide catalysts were studied and developed to improve the stability and activity of $\mathrm{CeO}_{2}$ catalysts. For instance, the $\mathrm{MnCeO}_{x}$ mixed oxide prepared by the sol-gel method exhibits a high catalytic activity and stability in the
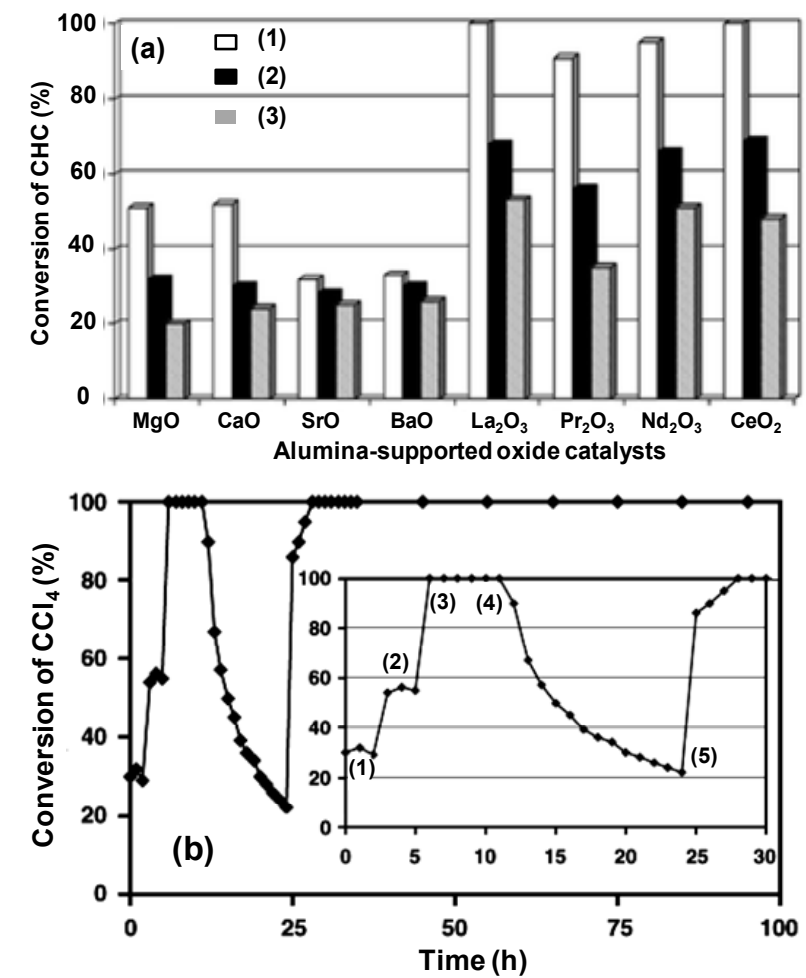

Fig. 8. Catalytic conversion of chlorinated hydrocarbons over alumina-supported alkaline earth metal and lanthanide oxides [100,101]. (a) Conversion of $\mathrm{CCl}_{4}$ (1), $\mathrm{CHCl}_{3}$ (2), and $\mathrm{CH}_{2} \mathrm{Cl}_{2}$ (3) over alumina-supported alkaline earth metal and lanthanide oxides after $7 \mathrm{~h}$ of operation at $350{ }^{\circ} \mathrm{C}$ and a GHSV of $800 \mathrm{~h}^{-1}$, the chlorinated hydrocarbon concentrations were 48000, 847000, and 105000 ppm, respectively; (b) Catalytic conversion of $\mathrm{CCl}_{4}$ over $10 \mathrm{wt} \% \mathrm{La}_{2} \mathrm{O}_{3} / \mathrm{Al}_{2} \mathrm{O}_{3}$ catalysts in the presence and absence of steam at various reaction temperatures as a function of reaction time $\left(\mathrm{GHSV}=800 \mathrm{~h}^{-1}\right.$ and inlet concentration of $\mathrm{CCl}_{4}=$ $47000 \mathrm{ppm}$ ): (1) $\mathrm{T}=250^{\circ} \mathrm{C}$, (2) $300{ }^{\circ} \mathrm{C}$, (3) $350{ }^{\circ} \mathrm{C}$, (4) $350{ }^{\circ} \mathrm{C}$; switching off the steam, and (5) $T=350^{\circ} \mathrm{C}$ with steam switched on. 


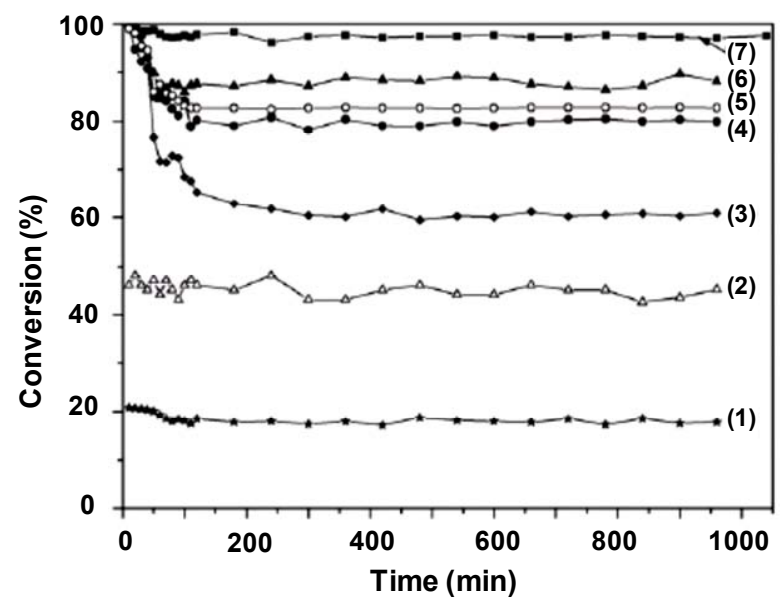

Fig. 9. Catalyst stability tests with different ratios of $\mathrm{Mn} / \mathrm{Mn}+\mathrm{Ce}$ for the catalytic combustion of chlorobenzene at $350{ }^{\circ} \mathrm{C}$ [105]. (1) $\mathrm{CeO}_{2}$; (2) $\mathrm{MnO}_{x ;}$ (3) 0.27; (4) 0.5; (5) 0.69; (6) 0.78; (7) 0.86. Gas composition: $1000 \mathrm{ppm}$ chlorobenzene, $10 \% \mathrm{O}_{2}$, balance of $\mathrm{N}_{2}$; GHSV $=15000 \mathrm{~h}^{-1}$.

catalytic combustion of chlorobenzene, as shown in Fig. 9 $[105,106]$. The catalytic activity and stability of the $\mathrm{MnCeO}_{x}$ catalyst are related to the particle size of the $\mathrm{MnCeO}_{x}$ solid solution, which has a fluorite-like structure with a large amount of surface oxygen that can adequately supply the oxidation reaction for the final removal of the formed chloride species. After incorporating La into the $\mathrm{MnCeO}_{x}$ solid solution, the stability of $\mathrm{MnCeO}_{x}$ can be improved further, because La enhances the oxygen mobility for the removal of adsorbed $\mathrm{Cl}$ species [107]. In addition to $\mathrm{CeO}_{2}$-based composite oxides, Ce-modified zeolites also exhibit high activity for the catalytic combustion of chlorinated hydrocarbon, especially Y zeolite [108,109]. The synergy between $\mathrm{CeO}_{2}$ species and $\mathrm{Y}$ zeolite leads to a more suitable combination of acidity and redox properties, and results in an enhancement of its catalytic activity. Furthermore, the addition of $\mathrm{CeO}_{2}$ to $\mathrm{Y}$ zeolite can adjust the surface acid properties and decrease coke deposition, which improves the durability of the catalysts $[110,111]$.

In the photocatalysts, the incorporation of rare earth materials into $\mathrm{TiO}_{2}$ can also extend light absorption from the ultraviolet to the visible region efficiently, which promotes the efficient application of $\mathrm{TiO}_{2}$ in air purification for indoor conditions of dim and visible light [112-114]. The combination of adsorption materials and photocatalysts can integrate the advantages of adsorption purification and photocatalytic purification, and thus provides a breakthrough for air purification techniques with high efficiency.

\section{Solid oxide fuel cells}

Fuel cells can transform chemical energy to electrical energy directly with a high energy conversion efficiency, and they are not restricted by the Carnot cycle. However, they hardly emit $\mathrm{NO}_{x}$ and $\mathrm{SO}_{x}$, and have $\mathrm{CO}_{2}$ emission that are less than $60 \%$ that from ordinary power plants. According to the electrolyte type, fuel cells can be classified into alkaline fuel cells, phosphoric acid fuel cells, proton exchange membrane fuel cells (PEMFCs), molten carbonate fuel cells and solid oxide fuel cells (SOFCs). Because the operating temperature is high $\left(800-1000{ }^{\circ} \mathrm{C}\right)$, and the residual heat can be used in combination with gas and steam turbines, the energy utilization by SOFCs is the highest among the fuel cells. Concurrently, noble catalysts are not required and many kinds of fuels (such as hydrogen, methane, and hydrocarbons) can be used in SOFCs. Therefore, SOFCs have been become very topical in fuel cell research after PEMFCs [115]. Park et al. [116] prepared SOFCs with $\mathrm{Cu}-\mathrm{CeO}_{2}$ anodes, and their open circuit voltages (OCVs) were $0.9 \mathrm{~V}$ in the direct electrochemical oxidation of hydrocarbons (methane, ethane, butane, and toluene) at 700 or $800^{\circ} \mathrm{C}$, in which the final products were $\mathrm{CO}_{2}$ and $\mathrm{H}_{2} \mathrm{O}$. The key components of SOFCs are mainly electrolyte, cathode, anode, and bipolar plate or interconnecting material (Fig. 10), and the rare earth elements play an important role in all the materials above.

In the case of the SOFC electrolytes, electrolytes with fluorite structure are mainly $\mathrm{ZrO}_{2}$ that is stabilized with $\mathrm{Y}_{2} \mathrm{O}_{3}$ (YSZ), Ce-based composite oxides, and $\mathrm{Bi}_{2} \mathrm{O}_{3}$-based materials. Among these materials, YSZ is the most widely used. Wang et al. $[117,118]$ found that adding $\mathrm{CeO}_{2}$ into scandia-stabilized zirconia (ScSZr) could improve its electrical conductivity significantly. The electrical conductivity of $\left(\mathrm{CeO}_{2}\right)_{0.01}-\left(\mathrm{Sc}_{2} \mathrm{O}_{3}\right)_{0.10^{-}}$ $\left(\mathrm{ZrO}_{2}\right)_{0.89}$ can reach $0.084 \mathrm{~S} / \mathrm{cm}$ at $800{ }^{\circ} \mathrm{C}$, while that of YSZ is only $\sim 0.04 \mathrm{~S} / \mathrm{cm}$ under the same conditions. $\mathrm{Bi}_{2} \mathrm{O}_{3}$-based materials are one of the oxygen ion conductors with the highest ion conductivity, and their conductivity can also be improved substantially by doping rare earth elements. For example, the conductivity of $\left(\mathrm{Bi}_{2} \mathrm{O}_{3}\right)_{0.8}\left(\mathrm{Er}_{2} \mathrm{O}_{3}\right)_{0.2}$ can reach $2.3 \mathrm{~S} / \mathrm{cm}$ at $500{ }^{\circ} \mathrm{C}$, and $37 \mathrm{~S} / \mathrm{cm}$ at $700{ }^{\circ} \mathrm{C}$ [119]. Recently, composite oxide electrolytes with perovskite structure have also been developed rapidly, such as $\mathrm{LaGaO}_{3}\left(\mathrm{La}_{1-x} \mathrm{Sr}_{x} \mathrm{Ga}_{1-y} \mathrm{Mg}_{y} \mathrm{O}_{3}, \mathrm{La}_{1-x} \mathrm{Sr}_{x} \mathrm{Ga}_{1-y} \mathrm{Co}_{y} \mathrm{O}_{3}\right)$ and $\mathrm{LnCoO}_{3}[120,121]$.

Electrode materials include cathode and anode materials. Cathode materials generally possess the following characteristics: excellent electrocatalytic activity, oxygen semi-permeability, mixed electronic-ionic conducting properties, and thermal expansion coefficient similar to solid oxide electrolyte. RE-based perovskite oxides, such as $\mathrm{La}_{1-x} \mathrm{Sr}_{x} \mathrm{Co}_{1-y} \mathrm{~B}_{y} \mathrm{O}_{3}(\mathrm{~B}=\mathrm{Ni}$, $\mathrm{Cu}), \mathrm{La}_{1-x} \mathrm{Sr}_{x} \mathrm{Mn}_{1-x} \mathrm{Sc}_{x} \mathrm{O}_{3}, \quad$ [122-124] and $\mathrm{Ba}_{1-x} \mathrm{Sr}_{x} \mathrm{Co}_{0.8} \mathrm{Fe}_{0.2} \mathrm{O}_{3-\delta}$ [125-127] can meet these requirements. Bi-layered composite cathodes of $\mathrm{La}_{0.8} \mathrm{Sr}_{0.2} \mathrm{MnO}_{3}$ (LSM)-YSZ and $\mathrm{LSM}-\mathrm{La}_{0.4} \mathrm{Ce}_{0.6} \mathrm{O}_{1.8}$ (LDC) were also fabricated for anode-supported solid oxide fuel cells with a thin YSZ electrolyte film [128]. The cell with bi-layered composite cathode exhibits a better performance than that with the corresponding single-layered composite cathode of LSM-LDC or LSM-YSZ. Anode materials generally possess the following characteristics: a high electrical conductivity, excellent electrocatalytic activity and gas permeability, excellent chemical compatibility, and thermal expansion compatibility with electrolyte materials. The anode of SOFC was mainly a Ni-based metal-ceramic composite electrode including $\mathrm{NiO} / \mathrm{YSZ}$ and doped materials, such as Ni-Cu-YSZ and $\mathrm{Ni}-\mathrm{Y}_{2} \mathrm{O}_{3}-\mathrm{ZrO}_{2}-\mathrm{TiO}_{2}$. However, Morales et al. [129] prepared an oxide anode of lanthanum-substituted strontium titanate (La-SrTiO ${ }_{3}$ ), in which the oxygen stoichiometry was controlled to create phases with considerable disordered oxygen defects 


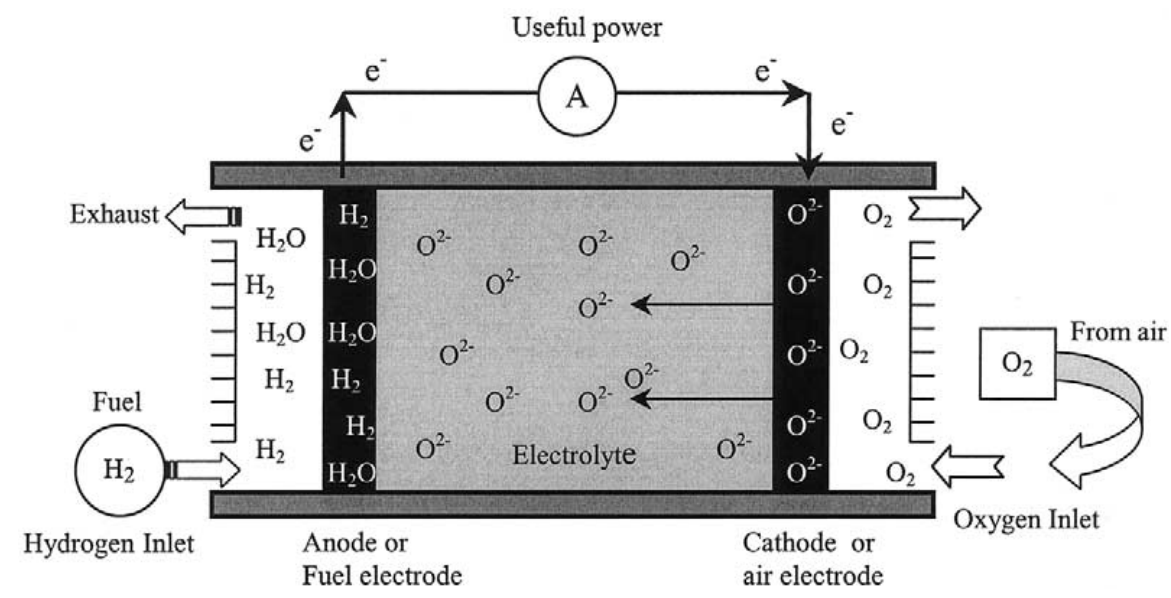

Fig. 10. Conceptual diagram of SOFC based on oxygen-ion conductors [115].

and some Ti was replaced with Ga and Mn to increase its redox activity. This anode is applicable in SOFCs for methane oxidation at high temperature, and the OCVs are over $1.2 \mathrm{~V}$, as shown in Fig. 11.

Interconnecting materials are mainly alloys (Ni-Cr) with high temperature resistance and doped perovskite-type composite oxides ( $\mathrm{La}_{1-x} \mathrm{Ca}_{x} \mathrm{CrO}_{3}$ or $\mathrm{La}_{0.8} \mathrm{Sr}_{0.2} \mathrm{Cr}_{0.9} \mathrm{Ti}_{0.1} \mathrm{O}_{3}$ ) [130,131]. To avoid the shortcomings of composite oxides, i.e. inferior sintering properties and their being difficult to shape, oxide-alloy composite interconnecting materials have attracted more attention, such as ( $\mathrm{La}, \mathrm{Sr}$ ) $\mathrm{CoO}_{3}$ thin film/Fe-Cr alloy and LCC/stainless steel.

\section{Theoretical research on RE catalysis}

Theoretical research on RE catalysis by simulation involves mainly the crystal and surface properties, and OSC of rare earth oxides (mainly $\mathrm{CeO}_{2}$ ), as well as the interaction between the rare earth oxides and noble metals. The crystal properties of $\mathrm{CeO}_{2}$ have been studied extensively using different theoretical methods, such as the interatomic potential function, generalized gradient approximation based on density functional theory (DFT), local density approximation based on DFT, DFT with

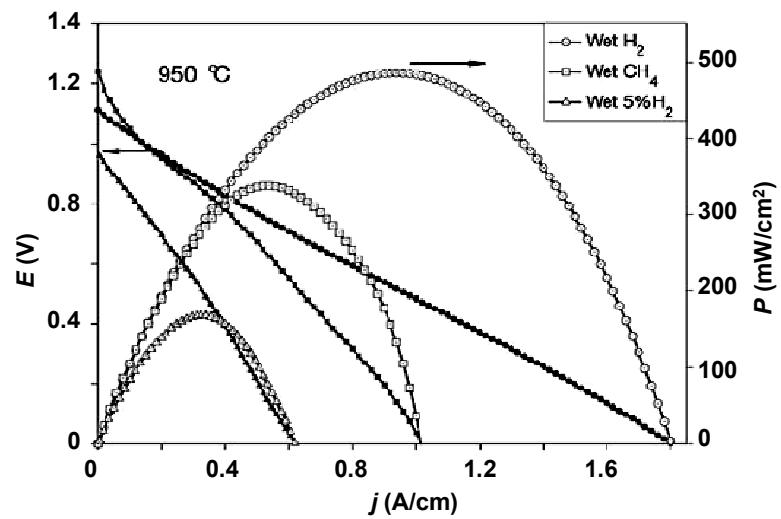

Fig. 11. Fuel cell performance plots for different fuel gas compositions each containing $2.3 \%$ water at $\mathrm{La}_{4} \mathrm{Sr}_{8} \mathrm{Ti}_{11} \mathrm{Mn}_{0.5} \mathrm{Ga}_{0.5} \mathrm{O}_{37.5}$ anode on a $330-\mu \mathrm{m}$-thin YSZ electrolyte, with $\mathrm{La}_{0.8} \mathrm{Sr}_{0.2} \mathrm{MnO}_{3}$ cathode in unhumidified oxygen [129]. a correction for on-site Coulomb interactions (DFT+U), and Hartree-Fock theory. The DFT methods used to calculate the electronic structures of $\mathrm{CeO}_{2}$ include: (1) the core-state model (CSM), in which Ce- $4 f$ electrons, as a part of the core, do not participate in bonding; (2) the valence-band model (VBM), in which Ce- $4 f$ electrons participate in bonding as valence electrons [132]; (3) DFT+U, in which the Hubbard-U Coulomb correction term is introduced on the basis of the VBM. The CSM can describe the structural properties and the electronic structure of $\mathrm{Ce}_{2} \mathrm{O}_{3}$, but it is not applicable to $\mathrm{CeO}_{2}$. In contrast, the VBM can describe the structural properties of $\mathrm{CeO}_{2}$, but it cannot describe the electronic structure of $\mathrm{Ce}_{2} \mathrm{O}_{3}$ and partially reduced $\mathrm{CeO}_{2-x}$. In a combined CSM and VBM, the distribution and addition of $\mathrm{Ce}^{3+}$ and $\mathrm{Ce}^{4+}$ in $\mathrm{CeO}_{2-x}$ must be determined artificially, and the structural properties of $\mathrm{CeO}_{2}$ are difficult to determine accurately. The introduction of Hubbard-U into DFT breaks the symmetrical distribution of $4 f$ electrons around $\mathrm{Ce}^{4+}$ to favor a localized distribution of $4 f$ electrons, and then describes the electronic structure of the Ce-O system.

Oxygen species on the surface and in the bulk of $\mathrm{CeO}_{2}$ can be consumed through reaction with the reactants, which results in the formation of oxygen vacancies. The formation and elimination of oxygen vacancies in $\mathrm{CeO}_{2}$ occur by the release and storage of oxygen, respectively. Therefore, the oxygen vacancy is an important parameter and active species for $\mathrm{CeO}_{2}$, which contains the formation and diffusion of oxygen vacancy.

Skorodumova et al. [133] found that the formation of oxygen vacancies on $\mathrm{CeO}_{2}$ was facilitated by a simultaneous condensation of two electrons into localized f-level traps on two cerium atoms. Based on a molecular mechanics study, Consa [134] and Sayle et al. [135] suggested that oxygen vacancies formed easily on the $\mathrm{CeO}_{2}$ surface and were more stable on (110) and (211) than on (111) facets. However, Yang et al. [136] revealed that the preferred vacancies were located in the subsurface layer (the second O-atomic layer) for the $\mathrm{CeO}_{2}$ (111) facet compared with the top-surface layer. Esch et al. [137] used DFT+U calculations and high-resolution scanning tunneling microscopy (STM) to investigate the local structure of surface and subsurface oxygen vacancies on the $\mathrm{CeO}_{2}$ (111) facet, and the formation and distribution of oxygen vacancies. The 
formation energy for two kinds of defects (within $10 \mathrm{meV}$ per vacancy) at the surface and subsurface was found to be equivalent. Recently, we also studied the formation of oxygen vacancies on $\mathrm{CeO}_{2}$ (111) by a DFT+U calculation, and found that the formation of subsurface vacancies were energetically more favored by comparing the formation energies between the top-surface and the subsurface single oxygen vacancy on $\mathrm{CeO}_{2}$ (111) [138]. It was suggested that the localized $4 f$ electrons, which were induced by the missing of a single oxygen, distributed at second- rather than at first-neighbor $\mathrm{Ce}^{3+}$.

The diffusion of oxygen vacancy is also crucial for the OSC of $\mathrm{CeO}_{2}$. Namai et al. [139] reported on single oxygen vacancy mobility even at room temperature. These results are in contrast with Esch's observations [137] that the direct diffusion of vacancies (i.e., hopping of the lattice oxygen) on this surface requires temperatures above $400{ }^{\circ} \mathrm{C}$. Recently, we revealed a two-step exchange mechanism for the diffusion of oxygen vacancies, which is described in Fig. 12 [140]. In this mechanism, a subsurface 0 near a top-surface 0 vacancy moves to fill the latter vacancy. A nearby top-surface 0 then moves to fill the newly formed subsurface 0 vacancy and in turn, generates a new top-surface 0 vacancy.

The introduction of $\mathrm{Zr}^{4+}$ in $\mathrm{CeO}_{2}$ can reduce the formation energy of the surface oxygen vacancy, and vacancy clusters can form without subsurface oxygen vacancies. For example, after the introduction of one $\mathrm{Zr}^{4+}$ into the $\mathrm{CeO}_{2}$ bulk with a 96-atom supercell, the $O$ vacancy formation energy is lowered substantially from 3.03 to $2.38 \mathrm{eV}$ when the 0 vacancy is created next to the $\mathrm{Zr}$ dopant [141]. Dutta et al. [142] considered that the introduction of $\mathrm{Zr}$ induced the formation of strong and weak-bonded oxygen, and that the latter was responsible for the higher oxygen storage capacity in the mixed oxides than in pure $\mathrm{CeO}_{2}$. Our research results based on $\mathrm{DFT}+\mathrm{U}$ calculations for the formation of $\mathrm{O}$ vacancies in a series of $\mathrm{Ce}_{1-x} \mathrm{Zr}_{x} \mathrm{O}_{2}$ materials show that the formation energy of the 0 vacancy is dependent on the bond energy $\left(E_{\text {bond }}\right)$ and relaxation energy $\left(E_{\text {re- }}\right.$ lax), as shown in Fig. 13 [143]. The relaxation energy is the dominating term and is determined by local topological structures around the $\mathrm{O}$ vacancy. On the basis of this model, we can pin down the key properties underlying the outstanding OSC of $\mathrm{k}-\mathrm{Ce}_{2} \mathrm{Zr}_{2} \mathrm{O}_{8}$ at the atomic level [144].

For the conversion of small molecules over rare earth oxides, Neurock et al. $[145,146]$ studied the effect of $\mathrm{O}^{2-}, \mathrm{O}^{-}, \mathrm{O}_{2}{ }^{2-}$, point defect, and $\mathrm{Sr}^{2+}$-doped surface sites on methane activation over the $\mathrm{La}_{2} \mathrm{O}_{3}(001)$ facet by DFT calculation. A possible mechanism for the oxidative coupling of methane over the $\mathrm{La}_{2} \mathrm{O}_{3}$ (001) facet has been suggested, in which surface peroxides are the active oxygen source. Yang et al. [136] studied different adsorption forms of $\mathrm{CO}$ on $\mathrm{CeO}_{2}(111)$ and $\mathrm{CeO}_{2}$ (110) by

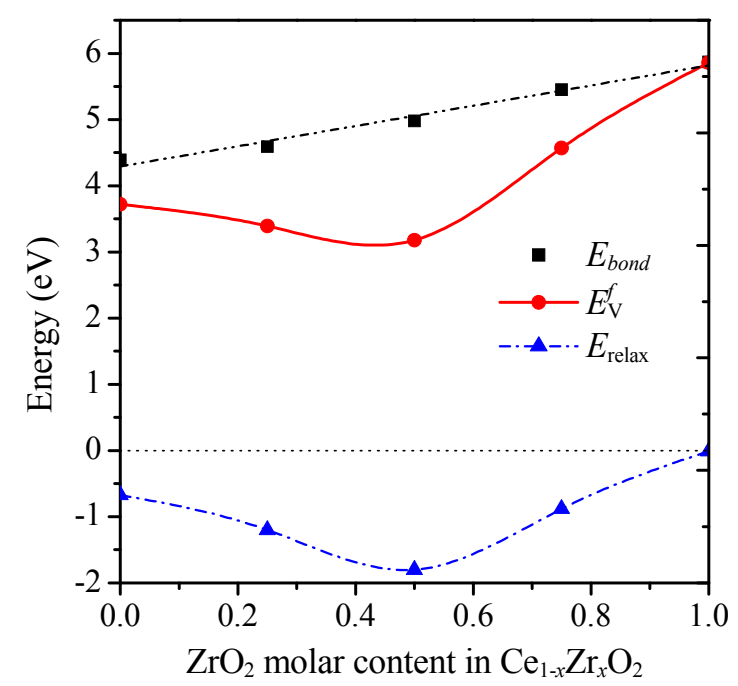

Fig. 13. Variations of $O$ vacancy formation energies, $E_{\mathrm{V}}^{\mathrm{f}}$, and related electrostatic ( $\left.E_{\text {bond }}\right)$ and structural relaxation $\left(E_{\text {relax }}\right)$ terms with respect to $\mathrm{ZrO}_{2}$ molar content in $\mathrm{Ce}_{1-x} \mathrm{Zr}_{x} \mathrm{O}_{2}$ [143].

DFT calculation within the generalized gradient approximation. Nolan et al. $[147,148]$ calculated the energies for the conversion of $\mathrm{CO}$ to $\mathrm{CO}_{2}, \mathrm{NO}_{2}$ to $\mathrm{NO}$, and $\mathrm{NO}$ to $\mathrm{N}_{2}$ over the $\mathrm{CeO}_{2}$ (111), (110), and (100) facets. Lattice oxygen on the (110) facet was the most favorable for the conversion of $\mathrm{CO}$ to $\mathrm{CO}_{2}$, and $\mathrm{NO}_{2}$ was easily reduced to NO over the (111) facet with oxygen vacancy defects. This is the reason for the higher catalytic activity of $\mathrm{CeO}_{2}$ nanowires for $\mathrm{CO}$ oxidation than that of $\mathrm{CeO}_{2} \mathrm{mi}-$ cro-particles, because the former exposes the (110) and (100) facets preferentially and the latter exposes the (111) facet preferentially.

$\mathrm{CeO}_{2}$ can be used as a catalyst, and also as a support for the noble metal and transition metal catalysts. To investigate the effect of the interaction between $\mathrm{CeO}_{2}$ and the noble metals on catalyst activity, Jung et al. [149] studied CO adsorption over $\mathrm{Pd}_{4}$ and $\mathrm{Pt}_{4}$ clusters supported on the $\mathrm{CeO}_{2}$ (111) facet, and clarified the effect of the support on $\mathrm{CO}$ activation. Liu et al. [150] studied the water-gas-shift (WGS) reaction over $\mathrm{Au} / \mathrm{CeO}_{2}$ using DFT calculation (Fig. 14), and found that the presence of empty localized nonbonding $4 f$ orbitals in $\mathrm{CeO}_{2}$ could promote the conversion of $\mathrm{Au}$ to $\mathrm{Au}^{\delta+}$, and enable subsequent $\mathrm{CO}$ adsorption. $\mathrm{Au}^{\delta+}$ combined with oxygen vacancies therefore became the active source for the WGS reaction, and $\mathrm{Au} / \mathrm{CeO}_{2}$ was more favorable for the WGS reaction. We studied Au nanoclusters (Au trimer, $\mathrm{Au}_{3}$ ) supported on the $\mathrm{CeO}_{2}$ surface by $\mathrm{DFT}+\mathrm{U}$ calculation [151] and found that $\mathrm{Au}_{3}$ can adsorb strongly on the $\mathrm{CeO}_{2}$ surface and reduce the $\mathrm{CeO}_{2}$ support partially by filling the originally empty $4 f$ orbital of one surface Ce with an elec-

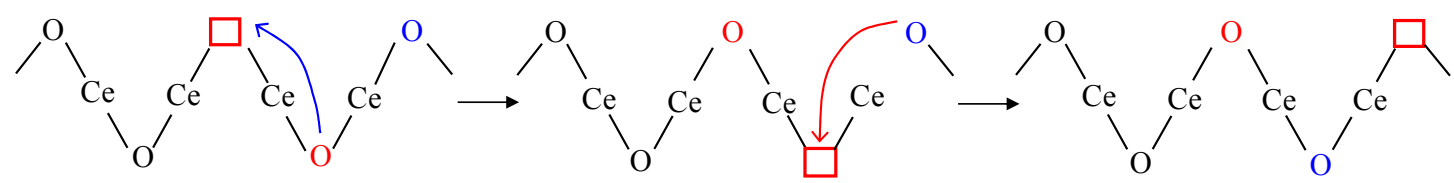

Fig. 12. Two-step exchange mechanism. Red boxes show 0 vacancies. Blue and red arrows indicate 0 diffusion from the sub- and top-surface positions to the 0 vacancies, respectively [140]. 


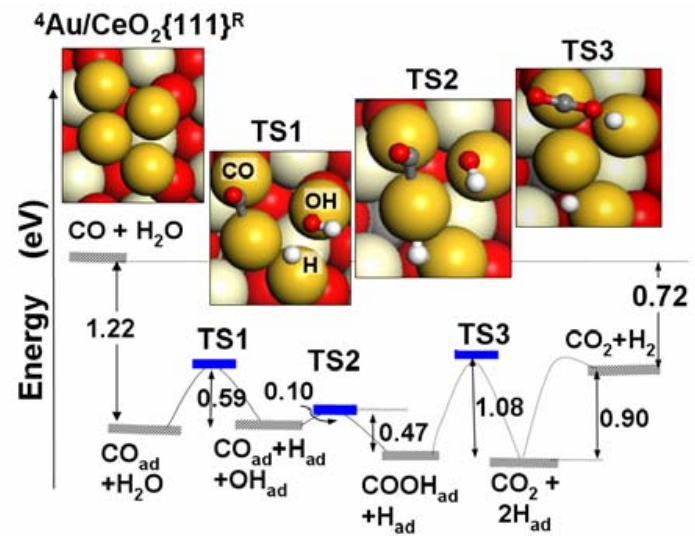

Fig. 14. Overall total-energy profile of $\mathrm{CO}+\mathrm{H}_{2} \mathrm{O} \rightarrow \mathrm{CO}_{2}+\mathrm{H}_{2}$ reaction on a four-atom $\mathrm{Au}$ cluster that anchors on an $\mathrm{O}$ vacancy of $\mathrm{CeO}_{2}$ (111) [150].

tron. Localized $4 f$ electrons can occur at different surface Ce atoms near the $\mathrm{Au}_{3}$ cluster corresponding to different surface relaxation configurations that are caused by $\mathrm{Au}_{3}$ adsorption. A calculation of the adsorption of $\mathrm{O}_{2}$ showed that only the surface Ce atoms at $\mathrm{Au}_{3} / \mathrm{CeO}_{2}(110)$ are capable of binding and activating $\mathrm{O}_{2}$.

Rare earth oxides play an irreplaceable role in many important catalysts, especially in solid catalysts or adsorbents, mainly as supports and additives. Although localized f electrons of rare earth elements make mathematical formulations and first-principle calculations difficult, which hinders research into the theoretical simulation of rare earth catalysis, the development of theoretical studies in this field is important and can help us to understand the nature of the rare earth catalysis.

\section{Summary and outlook}

Catalytic science and technology based on catalytic materials are the foundation for modern chemical industry development. Approximately $90 \%$ of chemical processes are dependent on catalysts. Every discovery of novel catalytic materials can promote step-change developments in the chemical industry. Therefore, research on catalytic materials is an important area in the chemical industry and in material science. Rare earth materials play an important and irreplaceable role in many catalytic materials, such as in three-way and FCC catalysts, because of their unique properties.

The introduction of rare earth materials into molecular sieves can adjust the amount and intensity distribution of acid sites to improve product distribution, and improve their structural stability. These are important for the practical application of zeolite catalysts for FCC.

For composite oxides, the introduction of rare earth materials: (1) regulates the acid-base properties of the catalyst surface; (2) strengthens the thermal stability of the oxide catalysts, especially their hydrothermal stability; (3) improves the oxide catalyst activity in catalytic combustion through the formation of perovskite-structured or hexaaluminate oxides; (4) increases the conductivity and electrocatalytic properties of the oxide, such as $\mathrm{LaGaO}_{3}$ and $\mathrm{La}_{1-x} \mathrm{Sr}_{x} \mathrm{MnO}_{3}$; and (5) improves the oxygen storage/release capacity to broaden the operating window of purification catalysts for automotive emissions, such as cerium zirconium solid solution and its derivatives.

In rare earth-noble metal catalysts, rare earth materials also play an important role in (1) improving the activity, selectivity, and catalyst stability, including: (2) improving the dispersion of the active metal, and decreasing the amount of noble metals to reduce catalyst costs; (3) improving poison tolerance and prolonging the catalyst life; (4) enhancing the catalyst coke-resistance; and (5)enhancing the adaptability of the catalyst to a rapid change in oxidation/reduction atmosphere.

Many challenges exist, such as how rare earth materials can play a greater role in catalytic materials, especially energetically and environmentally catalytic materials, as particular functional components or important promoters, and how to exploit their usage in novel catalytic processes or catalysts. For example, do the unique catalytic properties of rare earth elements result from their $4 f$ electrons, and if so, what is the role of $4 f$ electrons? Under what chemical reaction circumstances can rare earth elements better play a role in catalytic materials? What is the interaction mechanism between rare earth elements and other oxides, transition metals or noble metals? With the development of nanotechnology, materials science and modern characterization methods, investigations of the role of rare earth elements in catalytic materials at the molecular or atomic level are becoming possible. This presents new opportunities to design and prepare rare earth catalytic materials with high performance, to develop novel rare earth catalytic materials with an exciting structure and function, and to exploit new application fields.

\section{References}

[1] Carvajal R, Chu P J, Lunsford J H. J Catal, 1990, 125:123

[2] de la Puente G, Souza-Aguiar E F, Zotin F M Z, Camorim V L D, Sedran U. Appl Catal A, 2000, 197: 41

[3] Seherzer J, Ritter R E. Ind Eng Chem Prod Res Dev, 1978, 17: 219

[4] Magee J S, Comfier W E, Woltermann G M. Oil Gas J, 1985, 83(21): 59

[5] Yu S Q, Tian H P, Zhu Y X, Dai Z Y, Long J. Acta Phys-Chim Sin (于善 青, 田辉平, 朱玉霞, 代振宇, 龙军. 物理化学学报), 2011, 27: 2528

[6] Biswas J, Maxwell I E. Appl Catal, 1990, 63: 197

[7] Scherzer J. Catal Rev-Sci Eng, 1989, 31: 215

[8] Li B, Li S J, Li N, Liu C H, Gao X H, Pang X M. Chin J Catal (李斌, 李士 杰, 李能, 刘从华, 高雄厚, 庞新梅. 催化学报), 2005, 26: 301

[9] Dai Z Y, Shao Q, Li Y, He Z F, Zhou H. Aata Petrol Sin (Petrol Process Sec) (代振宇, 邵潜, 李阳, 贺振富, 周涵. 石油学报(石油加工)), 2007, 23(1): 41

[10] Rahimi N, Karimzadeh R. Appl Catal A, 2011, 398: 1

[11] Zhang P Q, Wang X S, Guo H C. Chin J Catal (张培青, 王祥生, 郭洪 臣. 催化学报), 2005, 26: 911

[12] Li Y F, Liu H, Zhu J Q, He P, Wang P, Tian H P. Microporous Mesoporous Mater, 2011, 142: 621

[13] Shao Q, Li Y, Tian H P, He Z F, Long J. Aata Petrol Sin (Petrol Process Sec) (邵潜, 李阳, 田辉平, 贺振富, 龙军. 石油学报(石油加工)), 2007, 23(2): 8

[14] Shao Q, Wang P, Tian H P, Yao R Y, Sun Y, Long J. Catal Today, 2009, 147: S347 


\section{Graphical Abstract}

Chin. J. Catal., 2014, 35: 1238-1250 doi: 10.1016/S1872-2067(14)60189-3

Current status and perspectives of rare earth catalytic materials and catalysis

Wangcheng Zhan, Yun Guo, Xueqing Gong, Yanglong Guo, Yanqing Wang, Guanzhong Lu* East China University of Science and Technology

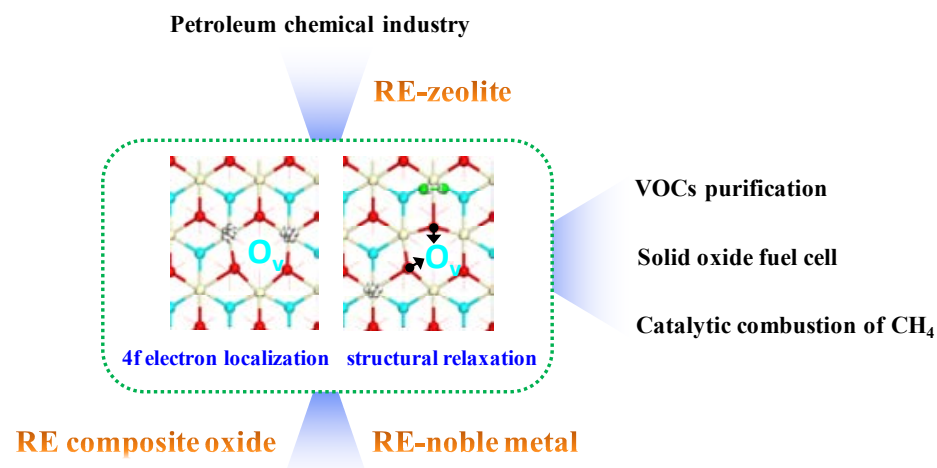

Automotive emission control

Rare earth elements have $4 f$ orbits without full electron occupancy and lanthanide contraction. This results in their unique catalytic performance when they are used as components and catalyst supports for many important chemical processes, such as in the petroleum chemical industry, in automotive emissions control, in the catalytic combustion of $\mathrm{CH}_{4}$, and in VOC purification.

[15] Ouyang J, Kong F X, Su G D, Hu Y C, Song Q L. Catal Lett, 2009, 132: 64

[16] Wang H J, Yu D H, Sun P, Yan J, Wang Y, Huang H. Catal Commun, 2008, 9: 1799

[17] Machado F J, López C M, Campos Y, Bolívar A, Yunes S. Appl Catal A, 2002, 226: 241

[18] Lopes J M, Ribeiro R F. J Mol Catal A, 2002, 179: 185

[19] Sheemol V N, Tyagi B, Jasra R V.J Mol Catal A, 2004, 215: 201

[20] Zhao R, Wang Y Q, Guo Y L, Guo Y, Liu X H, Zhang Z G, Wang Y S, Zhan W C, Lu G Z. Green Chem, 2006, 8: 459

[21] Li J, Li X, Shi Y, Mao D S, Lu G Z. Catal Lett, 2010, 137: 180

[22] Zwinkels M F M, Järas S G, Menon P G, Griffin T A. Catal Rev-Sci Eng, 1993, 35: 319

[23] Colussi S, Gayen A, Llorca J, de Leitenburg C, Dolcetti G, Tovarelli A. Ind Eng Chem Res, 2012, 51: 7510

[24] Choudhary T V, Banerjee S, Choudhary V R. Appl Catal A, 2002, 234: 1

[25] Forzatti P. Catal Today, 2003, 83: 3

[26] Cargnello M, Jaén J J D, Garrido J C H, Bakhmutsky K, Montini T, Gámez J J C, Gorte R J, Fornasiero P. Science, 2012, 337: 713

[27] Widjaja H, Sekizawa K, Eguchi K, Arai H. Catal Today, 1997, 35: 197

[28] Sekizawa K, Widjaja H, Maeda S, Ozawa Y, Eguchi K. Catal Today, 2000, 59: 69

[29] Colussi S, Gayen A, Farnesi C M, Boaro M, Llorca J, Fabris S, Trovarelli A. Angew Chem Int Ed, 2009, 48: 8481

[30] Schwartz W R, Pfefferle L D.J Phys Chem C, 2012, 116: 8571

[31] Ciuparu D, Lyubovsky M R, Altman E, Pfefferle L, Datye A. Catal Rev Sci Eng, 2002, 44: 593

[32] Groppi G, Cristiani C, Lietti L, Ramella C, Valentini M, Forzatti P. Catal Today, 1999, 50, 399

[33] Bernal S, Calvino J J, Gatica J M, Lopez Cartez C, Pintado J M. In: Trovarelli A Ed. Catalysis by Ceria and Related Materials. London: Imperial College, 2002. 85
[34] Hoflund G B, Li Z H, Epling W S, Göbel T, Schneider P, Hahn H. React Kinet Catal Lett, 2000, 70: 97

[35] Palmqvist A E C, Johansson E M, Jaras S G, Muhammed M. Catal Lett, 1998, 56: 69

[36] Kundakovic L, Flytzani-Stephanopoulos M. J Catal, 1998, 179: 203

[37] Deng Y Q, Nevell T G. Catal Today, 1999, 47: 279

[38] Machida M, Eguchi K, Arai H.J Catal, 1989, 120: 377

[39] Groppi G, Crisliani C, Forzatti P.J Catal, 1997, 168: 95

[40] Wang J W, Tian Z J, Xu J G, Xu Y P, Xu Z S, Lin L W. Catal Today, 2003, 83: 213

[41] Li T, Li Y D. Ind Eng Chem Res, 2008, 47: 1404

[42] Ren X G, Zheng J D, Song Y, Liu P J. Catal Commun, 2008, 9: 807

[43] Yu Y, Wang L S, Cui M S, Shi Y X, Luo R X, Chen A F. Rare Metals, 2011, 30: 337

[44] Zarur A J, Ying J Y. Nature, 2000, 403: 65

[45] Lu G Z, Zhang S H, Guo Y, Wang X Y, Guo Y L, Wang Y S, Liu X H (卢 冠忠, 张顺海, 郭耘, 王幸宜, 郭杨龙, 王筠松, 刘晓晖). CN Patent 1449863A. 2003

[46] Yin F X, Ji S F, Wu P Y, Zhao F Z, Li C Y.J Mol Catal A, 2008, 294: 27

[47] Gunasekaran N, Saddawi S, Carberry J J.J Catal, 1996, 159: 107

[48] Kirchnerova J, Klvana D. Solid State Ionics, 1999, 123: 307

[49] Song K S, Cui H X, Kim S D, Kang S K. Catal Today, 1999, 47: 155

[50] Choudhary V R, Banerjee S, Uphade B S. Appl Catal, 2000, 197: L183

[51] Pecchi G, Campos C, Peña O. Catal Today, 2011, 172: 111

[52] Wang Y G, Ren J W, Wang Y Q, Zhang F Y, Liu X H, Guo Y, Lu G Z.J Phys Chem C, 2008, 112: 15293

[53] Liang S H, Xu T G, Teng F, Zong R L, Zhu Y F. Appl Catal B, 2010, 96: 267

[54] Cimino S, Pirone R, Lisi L. Appl Catal B, 2002, 35: 243

[55] Salomonsson P, Grifin T, Kasemo B. Appl Catal A, 1993, 104: 175

[56] Peter S D, Garbowski E, Perrichon V, Primet M. Catal Lett, 2000, 70: 27

[57] Cimino S, Benedetto A D, Pirone R, Russo G. Catal Today, 2001, 69: 
95

[58] Yi N, Cao Y, Su Y, Dai W L, He H Y, Fan K N.J Catal, 2005, 230: 249

[59] Adams K M, Cavataio J V, Hammerle R H. Appl Catal B, 1996, 10:157

[60] Allanson R, Blakeman P G, Cooper B J, Hess H, Silcock P J, Walker A P. Soc Automot Eng, 2002, SP-1673: 53

[61] Page D L, Macdonald R J, Edgar B L. Soc Automot Eng, 1999, SP-1469: 61

[62] Hung W T. Energy Policy, 2006, 34: 2566

[63] Winebrake J J, Wang M Q, He D Q. J Air Waste Manage, 2001, 51(7): 1073

[64] Huai T, Durbin T D, Rhee S H, Norbeck J M. Inter J Auto Tech, 2003, 4: 9

[65] Kašpar J, Fornasiero P, Hickey N. Catal Today, 2003, 77: 419

[66] Heck R M, Farrauto R J. Appl Catal A, 2001, 221: 443

[67] Lafyatis D S, Ansell G P, Benneu S C, Frost J C, Millington P J, Rajaram R R, Walker A P, Ballinger T H. Appl Catal B, 1998, 18: 123

[68] Nishihata Y, Mizuki J, Akao T, Tanaka H, Uenishi M, Kimura M, Okamoto T, Hamada N. Nature, 2002, 418: 164

[69] Burch R. Catal Rev-Sci Eng, 2004, 46: 271

[70] Shelef M, McCabe R W. Catal Today, 2000, 62: 35

[71] Wu X D, Weng D. J Rare Earths, 2004, 22: 837

[72] Kašpar J, Di Monte R, Fornasiero P, Graziani M, Bradshaw H, Norman C. Top Catal, 2001, 16: 83

[73] He H, Dai H X, Wong K W, Au C T. Appl Catal A, 2003, 251: 61

[74] Fomasiero P, Balducci G, Di Monte R, Kašpar J, Sergo V, Gubitosa G, Ferrero A, Graziani M. J Catal, 1996, 164: 173

[75] Sugiura M. Catal Surv Asia, 2003, 7: 77

[76] Nagai Y, Yamamoto T, Tanaka T, Yoshida S, Nonaka T, Okamoto T, Suda A, Sugiura M. Catal Today, 2002, 74: 225.

[77] Dong F, Suda A, Tanabe T, Nagai Y, Sobukawa H, Shinjoh H, Sugiura M, Descorme C, Duprez D. Catal Today, 2004, 90: 223

[78] Zhao M W, Shen M Q, Wang J.J Catal, 2007, 248: 258

[79] Rohart E, Larcher O, Deutsch S, Hédouin C, Aïmin H, Fajardie F, Allain M, Macaudière P. Top Catal, 2004, 30/31: 417

[80] Matsumoto S. Catal Today, 2004, 90: 183

[81] Jiang P P, Lu G Z, Guo Y L, Guo Y, Wang Y S, Zhang S H, Wang X Y. Chin J Inorg Chem (蒋平平, 卢冠忠, 郭杨龙, 郭耘, 王筠松, 张顺 海, 王幸宜. 无机化学学报), 2004, 20: 1390

[82] Roy S, Hegde M S, Madras G. Appl Energy, 2009, 86: 2283

[83] Brandenberger S, Kröcher 0, Tissler A, Althoff R. Catal Rev Sci Eng, 2008, 50: 492

[84] Long R Q, Yang R T.J Am Chem Soc, 1999, 121: 5595

[85] Shan W P, Liu F D, He H, Shi X Y, Zhang C B. Chem Commun, 2011, 47: 8046

[86] Takahashi N, Shinjoh H, Iijima T, Suzuki T, Yamazaki K, Yokota K, Suzuki H, Miyoshi N, Matsumoto S, Tanizawa T, Tanaka T, Tateishi S, Kasahara K. Catal Today, 1996, 27: 63

[87] Matsumoto S. Catal Today, 2004, 90: 183

[88] Piacentini M, Maciejewski M, Baiker A. Top Catal, 2007, 42-43: 55

[89] Strobel R, Krumeich F, Pratsinis S E, Baiker A. J Catal, 2006, 243: 229

[90] Corbos E C, Courtois X, Bion N, Marecot P, Duprez D. Appl Catal B, 2007, 76: 357

[91] Kim C H, Qi G, Dahlberg K, Li W. Science, 2010, 327: 1624

[92] Hibbert D B. Catal Rev Sci Eng, 1992, 34: 391

[93] Cheng W C, Kim G, Peters A W, Zhao X, Rajagopalan K, Ziebarth M S, Pereira C J. Catal Rev-Sci Eng, 1998, 40: 39

[94] Hedges S W, Yeh J T. Environ Prog, 1992, 11(2): 98

[95] Waqif M, Bazin P, Saur O, Lavalley J C, Blanchard G, Touret O. Appl Catal B, 1997, 11: 193

[96] Trovarelli A, de Leitenburg C, Boaro M, Dolcetti G. Catal Today,
1999, 50: 353

[97] Bagllo J A. Ind Eng Chem Prod Res Dev, 1982, 21: 38

[98] Hibbert D B, Campbell R H. Appl Catal, 1988, 41: 289

[99] Liu W, Wadia C, Flytzani-Stephanopoulos M. Catal Today, 1996, 28: 391

[100] Van der Avert P, Wechuysen B M. Angew Chem Int Ed, 2002, 41: 4730

[101] Van der Avert P, Wechuysen B M. Phys Chem Chem Phys, 2004, 6: 5256

[102] Wang X Y, Dai Q G, Zheng Y. Chin J Catal (王幸宜, 戴启广, 郑翊. 催化学报), 2006, 27: 468

[103] Dai Q G, Wang X Y, Lu G Z. Appl Catal B, 2008, 81: 192

[104] Dai Q G, Huang H, Zhu Y, Deng W, Bai S X, Wang X Y, Lu G Z. Appl Catal B, 2012, 117-118: 360

[105] Wang X Y, Kang Q Li D. Appl Catal B, 2009, 86: 166

[106] Wang X Y, Kang Q Li D. Catal Commun, 2008, 9: 2158

[107] Dai Y, Wang X Y, Li D, Dai Q G.J Hazard Mater, 2011, 188: 132

[108] Zhou J M, Zhao L, Huang Q Q Zhou R X, Li X K. Catal Lett, 2009, 127: 277

[109] Huang Q Q, Xue X M, Zhou R X. J Hazard Mater, 2010, 183: 694

[110] Huang Q Q Zuo S F, Zhao B, Zhou R X. J Mol Catal A, 2010, 331: 130

[111] Huang Q Q, Xue X M, Zhou R X. J Mol Catal A, 2011, 344: 74

[112] Xu A W, Gao Y, Liu H Q. J Catal, 2002, 207: 151

[113] Zhang Y H, Zhang H X, Xu Y X, Wang Y G. J Solid State Chem, 2004, 177: 3490

[114] Hassan M S, Amna T, Yang O B, Kim H C, Khil M S. Ceram Int, 2012, 38: 5925

[115] Stambouli A B, Traversa E. Renew Sust Energ Rev, 2002, 6: 433

[116] Park S, Vohs J M, Gorte R J. Nature, 2000, 404: 265

[117] Wang Z W, Cheng M J, Dong Y L, Zhang M, Zhang H M. J Power Sources, 2006, 156: 306

[118] Wang Z W, Cheng M J, Bi Z H, Dong Y L, Zhang H M, Zhang J, Feng Z C, Li C. Mater Lett, 2005, 59: 2579

[119] Verkerk M J, Keizer K, Burggraaf A J. J Appl Electrochem, 1980, 10: 81

[120] Ishihara T, Matsuda H, Takita Y. J Am Chem Soc, 1994, 116: 3801

[121] Kuroda K, Hashimoto I, Adachi K, Akikusa J, Tamou Y, Komada N, Ishihara T, Takita Y. Solid State Ionics, 2000, 132: 199

[122] Sakaki Y, Takeda Y, Kato A, Imanishi N, Yamamoto O, Hattori M, Iio M, Esaki Y. Solid State Ionics, 1999, 118: 187

[123] Yue X L, Yan A Y, Zhang M, Liu L, Dong Y L, Cheng M J. J Power Sources, 2008, 185: 691

[124] Yang M, Zhang M, Yan A Y, Yue X L, Hou Z F, Dong Y L, Cheng M J. Electrochem Solid State Lett, 2008, 11: B34

[125] Yang M, Zhang M, Yan A Y, Yue X L, Hou Z F, Dong Y L, Cheng M J. J Power Sources, 2008, 185: 784

[126] Yan A Y, Liu B, Dong Y L, Tian Z J, Wang D Z, Cheng M J. A Appl Catal B, 2008, 80: 24

[127] Yan A Y, Yang M, Hou Z, Dong Y L, Cheng M J. J Power Sources, 2008, 185: 76

[128] Zhang M, Yang M, Hou Z F, Dong Y, Cheng M. Electrochim Acta, 2008, 53: 4998

[129] Ruiz-Morales J C, Canales-Vázquez J, Savaniu C, Marrero-López D, Zhou W Z, Irvine J T S. Nature, 2006, 439: 568

[130] Huang K, Wan J, Goodenough J B. J Mater Sci, 2001, 36: 1093

[131] Moil M.J Electrochem Soc, 2002, 149: A797

[132] Fabris S, de Gironcoh S, Baroni S, Vicario G, Balducci G. Phys Rev $B, 2005,71: 041102$

[133] Skorodumova N V, Simak S I, Lundqvist B I, Abrikosov I A, Johansson B. Phys Rev Lett, 2002, 89: 166601

[134] Consa J C. Surf Sci, 1995, 339: 337 
[135] Sayle T X T, Parker S C, Catlow C R A. Surf Sci, 1994, 316: 329

[136] Yang Z X, Woo T K, Baudin M, Hermansson K. J Chem Phys, 2004, 120: 7741

[137] Esch F, Fabris S, Zhou L, Montini T, Africh C, Fornasiero P, Comelli G, Rosei R. Science, 2005, 309: 752

[138] Li H Y, Wang H F, Gong X Q, Guo Y L, Guo Y, Lu G Z, Hu P. Phys Review B, 2009, 79: 193401-4

[139] Namai Y, Fukui K, Iwasawa Y.J Phys Chem B, 2003, 107: 11666

[140] Li H Y, Wang H F, Guo Y L, Lu G Z, Hu P. Chem Commun, 2011, 47: 6105

[141] Yang Z X, Woo T K, Hermansson K. J Chem Phys, 2006, 124: 224704

[142] Dutta G, Waghmare U V, Baidya T, Hegde M S, Priolkar K R, Sarode P R. Catal Lett, 2006, 108: 165

[143] Wang H F, Gong X Q, Guo Y L, Guo Y, Lu G Z, Hu P. J Phys Chem C,
2009, 113: 10229

[144] Wang H F, Gong X Q, Guo Y L, Guo Y, Lu G Z, Hu P. Angew Chem Int $E d, 2009,48: 8289$

[145] Palmer M S, Neurock M, Olken M M. J Am Chem Soc, 2002, 124: 8452

[146] Palmer M S, Neurock M, Olken M M. J Phys Chem B, 2002, 106: 6543

[147] Nolan M, Parker S C, Watson G W. Phys Chem Chem Phys, 2006, 8: 216

[148] Nolan M, Parker S C, Watson G W. J Phys Chem B, 2006, 110: 2256

[149] Jung C, Tsuboi H, Koyama M, Kubo M, Broclawik E, Miyamoto A. Catal Today, 2006, 111: 322

[150] Liu Z P, Jenkins S J, King D A. Phys Rev Lett, 2005, 94: 196102

[151] Zhu W J, Zhang J, Gong X Q, Lu G Z. Catal Today, 2011, 165: 19

\section{稀土催化材料的应用及研究进展}

詹望成, 郭耘, 龚学庆, 郭杨龙, 王艳芹, 卢冠忠 ${ }^{*}$

华东理工大学化学与分子工程学院工业催化研究所, 上海200237

摘要: 稀土元素具有未充满电子的 $4 f$ 轨道和镧系收缩等特征, 当用作催化剂的活性组分或载体时常常表现出独特的催化性能. 稀 土催化材料的研究和发展为 $\mathrm{La}$ 和 $\mathrm{Ce}$ 等高丰度轻稀土元素的高质、高效利用提供了有效的途径. 目前稀土催化材料在石油化工、 化石燃料的催化燃烧、机动车尾气净化、工业废气治理和固体氧化物燃料电池等领域发挥着重要的作用. 本文综述了稀土催化 材料的应用以及理论研究进展, 重点讨论了稀土元素对所涉及催化剂的结构、活性和稳定性等的影响.

关键词：稀土催化材料；环境保护；清洁能源；密度泛函理论计算；氧化铈催化

收稿日期: 2014-06-13. 接受日期：2014-07-01. 出版日期: 2014-08-20.

*通讯联系人.电话/传真: (021)64252923; 电子信箱: gzhlu@ecust.edu.cn

基金来源：国家重点基础研究发展计划(973计划, 2010CB732300); 国家高技术研究发展计划(863计划, 2012AA111717); 中央高

校基本科研业务费专项资金(WK1214007); 国家自然科学基金(21273150, 21103048).

本文的英文电子版由Elsevier出版社在ScienceDirect上出版(http://www.sciencedirect.com/science/journal/18722067). 